Int. J. Dev. Biol. 62: 473-477 (2018)

https://doi.org/10.1387/ijdb.170331hr

\title{
Linking wound response and inflammation to regeneration in the zebrafish larval fin
}

\author{
HENRY HAMILTON ROEHL* \\ Department of Biomedical Sciences, University of Sheffield, Sheffield, South Yorkshire, UK.
}

\begin{abstract}
The study of regenerative biology aims to elucidate the innate ability of organisms to replace tissues or organs after they have been removed or damaged. The zebrafish is a powerful model for the analysis of intracellular signalling and cell behaviour and as such has made major contributions to our understanding of regenerative biology. The larval fin fold is an emerging model to understand how different signalling pathways interact to coordinate regeneration. Tissue damage causes the immediate release of signals that initiate wound closure and inflammation. Following this, regenerative cells proliferate and migrate to the damaged area. Each of these processes has been analysed using the larval fin fold model to provide a framework for how fin regeneration takes place. This review gives an overview of the current state of this field with particular emphasis on the different signalling networks that are required during fin fold regeneration.
\end{abstract}

KEY WORDS: zebrafish, fin, regeneration, regenerative biology

\section{Introduction}

Many of the unique experimental attributes of the zebrafish model are present before fish begin to feed, during the embryonic (0-48 hours post fertilisation (hpf)) and early larval (48hpf-120hpf) stages. At this time the fish are small, transparent and easily immobilised allowing researchers to make live microscopic observations for extended periods of time. Large numbers of eggs can be produced quickly, and larvae can be maintained for days in as little as 100 microliters of water. As most pharmaceuticals diffuse freely into the fish, pharmacological tests can be performed by simply adding compounds to the fish water. Many mutations are not homozygous viable as adult but survive until $120 \mathrm{hpf}$ and thus provide important tools to assess regenerative gene function in larvae. In addition, experiments done before the fish begin to feed have fewer ethical and legal considerations.

Zebrafish regeneration research has primarily focused upon adult tissues such as spinal cord, fin and heart and by comparison, there are relatively few studies that focus on larval regeneration. One reason for this may be the assumption that regeneration at larval stages utilises different mechanisms than that of the adult (Kawakami et al., 2004, Yoshinari and Kawakami, 2011). Whilst the fish is rapidly growing and still developing there are many stem cells or groups of precursors cells present that are likely to contribute to regeneration. As development is ongoing, the replacement of lost tissue may simply be an extension of normal development. A further point to consider is that organs such as the heart are likely to be smaller and less complex in young fish. So, focusing on the adult may reduce the impact of developmental mechanisms and allow one to study regeneration of fully differentiated and complex tissues and organs. In other words, experiments on adult fish perhaps represent the most stringent test of regenerative capability.

Although these reasons are worth considering, the study of larval zebrafish continues to grow in popularity. The success of larval studies on damage-induced signals and the immune response have created a strong base from which to assemble the steps involved in regeneration. This review focuses on the larval fin fold and attempts to follow the initial stages of wound response and inflammation and link these to subsequent regeneration. A summary of these

\footnotetext{
Abbreviations used in this paper: citral, 3,7-dimethyl-2,6-octadienal; cloche, neuronal PAS domain protein 4 like; Csf3r, colony stimulating factor 3 receptor (granulocyte); DEAB, N,N-diethylaminobenzaldehyde; Dlx, distal-less homeobox; ErbB, erb-b receptor tyrosine kinase; Fam53b, family with sequence similarity 53, member B; FGF, fibroblast growth factor; Fyn, FYN proto-oncogene; Il1 $\beta$, interleukin 1 , beta; Irf8, interferon regulatory factor 8; JNK, c-Jun NH(2)-terminal kinase; Jun, Jun proto-oncogene; Lyn, LYN proto-oncogene; Msx, muscle segment homeobox; RA, retinoic acid; Runx1, runt-related transcription factor 1; Spilb, Spi-1 proto-oncogene b; SU5402, 2-[(1,2-Dihydro-2-oxo-3H-indol-3-ylidene)methyl]4-methyl-1H-pyrrole-3-propanoic acid; Tall, T-cell acute lymphocytic leukemia 1; WNT, wingless-type MMTV integration site family.
}

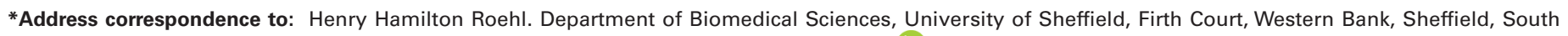
Yorkshire, United Kingdom, S10 2TN.Tel: 44114222 2351. E-mail: h.roehl@ sheffield.ac.uk - iD https://orcid.org/0000-0001-6497-2405 
findings is presented in Fig. 1. Other emerging larval models that are not discussed here are neural regeneration (Liu et al., 2016, Lush and Piotrowski, 2014, Meyers et al., 2012, O'Brien et al., 2009a, O'Brien et al., 2009b, Ohnmacht et al., 2016, Rieger and Sagasti, 2011, Rosenberg et al., 2014, Sieger et al., 2012), muscle regeneration (Knappe et al., 2015, Pipalia et al., 2016, Rodrigues et al., 2012, Seger et al., 2011) and liver regeneration (He et al., 2014, Huang et al., 2014). In addition to research specifically framed to investigate regeneration, there are many studies that could also be considered to address questions of regeneration that are not discussed here. These include experimental biology approaches such as cell ablation, mutations that result in degeneration such as muscular dystrophy and studies of responses to toxicity.

\section{Fin fold regeneration}

\section{Overview}

The median fin fold is a transient structure that begins to form during somitogenesis ( $\sim 15 \mathrm{hpf})$ and is resorbed and replaced by the dorsal, caudal and anal fins during metamorphosis (Parichy et al., 2009). It is made up of a folded layer of epidermis that extends dorsally, caudally and ventrally from the posterior two thirds of the body. The epidermis is one to two cells thick during the time points that are generally analysed for regeneration. It is supported by actinotrichia which are collagen-rich fibrillar structures that are found in a layer directly underneath the epithelia. In the centre of the fin fold there are fin mesenchymal cells that associate with actinotrichia, sensory axons as well as scattered pigment cells and leucocytes. Excision of the caudal end of the fin fold is done with a fine scalpel between the 48 and $72 \mathrm{hpf}$ and it takes 2-4 days for regrowth to complete (Kawakami et al., 2004, Lisse et al., 2015, Yoshinari and Kawakami, 2011) (Fig. 2). Regeneration of limbs in amphibians is characterised by formation of a thickened epithelium (wound epithelium) that is marked by expression $d l x$ genes. The wound epithelium overlays densely packed proliferative cells (the blastema) that will give rise to new tissue and express msx genes. Similarly, by 24 hours post excision (hpe) the wound epithelium of the fin fold is marked by expression of $d l x 5 a$ and the blastema by expression of msxc and msxe (Kawakami et al., 2004). Cells that will give rise to the blastema originate from areas around the notochord and begin their migration distally within an hour of wounding (Mateus et al., 2012). These cells become rounded and their nuclei become condensed, but unlike blastemal cells in other systems, they do not proliferate rapidly: damage-induced cell division in the fin fold is more diffuse spreading throughout the posterior trunk (Kawakami et al., 2004, Mateus et al., 2012).

\section{Transcription-independent damage signals}

When the skin is breached, signals released in the first seconds and minutes ensure that the wound is rapidly closed to restore the internal environment and to reduce the risk of pathogen infiltration (Cordeiro and Jacinto, 2013, Niethammer, 2016). Osmotic shock and mechanical damage along the margin of the wound cause the immediate release of damage associated molecular patterns (DAMPs) such as ATP that communicate to the immune system (de Oliveira et al., 2015, de Oliveira et al., 2014). In addition, within seconds intracellular calcium $\left(\mathrm{Ca}^{2+}\right)$ is elevated at the margin, and this increase is then propagated to over $200 \mu \mathrm{m}$ deep into the fish (Enyedi et al., 2016, Yoo et al., 2012). $\mathrm{Ca}^{2+}$ causes the release of

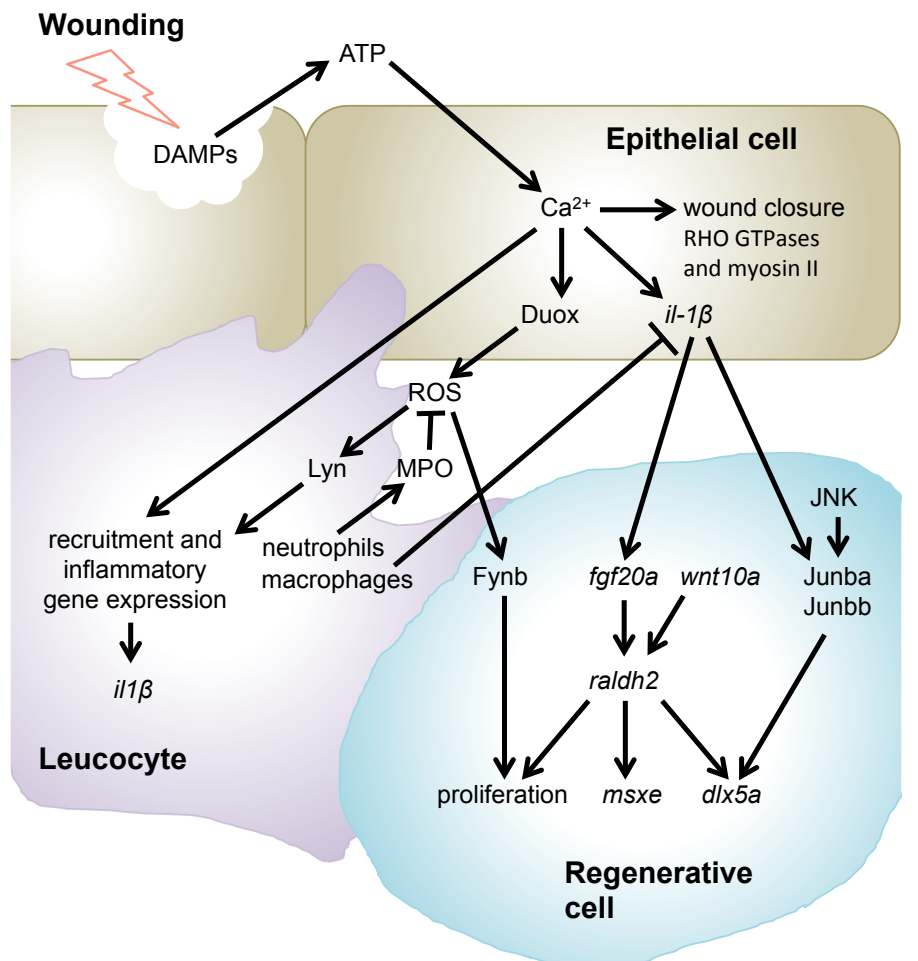

Fig. 1. A model of signaling network interactions during fin fold regeneration. See the text for details.

eicosanoids which act to attract leucocytes (Enyedi et al., 2016). Evidence from other models suggests that $\mathrm{Ca}^{2+}$ also acts through Rho family GTPases to reorganise actin and myosin II in epithelia to draw the wound closed (Cordeiro and Jacinto, 2013, Niethammer, 2016). Within minutes, reactive oxygen species (ROS) are synthesised by the flavoenzyme dual oxidase (Duox) at the wound margin and then diffuse up to $200 \mu \mathrm{m}$ into the fish (Niethammer et al., 2009, Rieger and Sagasti, 2011). The predominant form of ROS is likely to be $\mathrm{H}_{2} \mathrm{O}_{2}$ as other species are too reactive to diffuse this far. Like the other signals, ROS act on the immune system to attract leucocytes to the wound and do so by activating a Src family kinase (SFK) called Lyn (Niethammer et al., 2009, Yoo et al., 2011). As neutrophils arrive at the wound they release myeloperoxidase which breaks down $\mathrm{H}_{2} \mathrm{O}_{2}$ to dampen $\mathrm{ROS}$ signalling (Pase et al., 2012). These three early signals may form a linear pathway (Cordeiro and Jacinto, 2013, de Oliveira et al., 2015, de Oliveira et al., 2014, Niethammer, 2016). This sequence begins when damaged cells release ATP which then activates purinergic receptors in neighbouring intact cells, that causes elevation of intracellular $\mathrm{Ca}^{2+}$, which activates Duox causing synthesis of ROS. Although this cascade is probably central in the early response it is perhaps an oversimplified view of the first few minutes after wounding. It is likely that there is feedback between these pathways, as well as other early pathways that contribute to the initial response.

\section{Regeneration signalling pathways}

After the initial response to wounding, the organism needs to recruit cells to rebuild the missing tissue. These cells need to proliferate, be patterned, go through morphogenesis and differentiate. As in development these processes are likely to involve many 
signalling pathways. Although the fin fold is a very simple tissue, it is already apparent that the networks involved in restoration of the tissue are complex and numerous.

Developmental signalling pathways have understandably been heavily investigated for their roles in fin fold regeneration. The FGF receptor inhibitor SU5402 has been used to show that FGF signalling promotes damage induced cell proliferation (Kawakami et al., 2004). Mathew et al., found that the RA synthesis gene raldh2 is induced by 4 hpe and that RA synthesis inhibitors DEAB and Citral also block $m s x$ and $d / x$ gene expression as well as damage-induced proliferation (Mathew et al., 2009). Mathew et al., also investigated the role of the FGF and WNT/ $\beta$ catenin pathways using SU5402 as well as a dominant negative transgene to target $W N T / \beta$-Catenin signalling. Their results suggest the model that FGF and WNT/ $\beta$-Catenin pathways activate RA signalling which patterns the regenerating fin fold and drives proliferation. How these interactions relate to the initial formation of the fin fold is currently unclear as fin fold development is an understudied area.

Upstream of developmental signalling there are pathways involved with stress response and inflammation. Expression of the JNK signalling components junba, junbb and $c$-jun is strongly induced within 30 minutes of damage indicating that they are immediate early genes (Ishida et al., 2010). Phosphorylation of Jun proteins occurs by the wound within minutes of excision and inhibition with the JNK inhibitor SP600125 blocks proliferation and regeneration. Similarly, the cytokine $i l 1 \beta$ is upregulated in the epidermis by 3 hpe and it is required for cell proliferation as well as expression of fgf20a and junba (Hasegawa et al., 2017). il1 $\beta$ is also known in other systems to be transcriptionally activated by the JNK pathway (Newton and Dixit, 2012), so it is possible that the upregulation of junba is part of a positive feedback loop.

\section{Linking damage signals to regeneration}

How does an organism sense that a tissue or an organ is missing, what molecules trigger regeneration and what determines whether the wound is simply healed over to leave a scar or replaced? The answers to these questions may hold the key to initiating human regeneration and have understandably been the focus of much research on the larval fin fold. Two candidates that may link the early wound response to regeneration have emerged in the last few years.

Inflammatory signals and leucocytes are thought to play a complex role in regeneration in many systems (Eming et al., 2017). Analysis of the fin fold has yielded conflicting results over the last decade, but recent data has begun to support a nuanced role for inflammation during the initiation of regeneration. Neutrophils are attracted to the wounded fin fold within minutes

Fig. 2. Larval zebrafish fin fold regeneration. (A) Larval fish at 72 hpf showing the possition for excision of the fin fold (dotted line on the right) and the possition for tail excision (dotted line on the left). Scale bar equals $500 \mu \mathrm{m}$. (B) Close-up images of the fin fold before and after excision. Larvae are 72 hpf. (C) Close-up images of the fin fold after 48 hours of recovery when the fin has almost completely regenerated. Larvae are $120 \mathrm{hpf}$. Scale bar, $100 \mu \mathrm{m}$. and their presence peaks at about 4hpe, while macrophage numbers peak several hours later. Initially, two studies that used a pu. 1 morpholino to target macrophages and neutrophils found that leucocytes are dispensable for regeneration (Mathew et al., 2007, Yoo et al., 2012). In contrast, another study that compared the individual roles for leucocytes by removing macrophages with an irf8 morpholino and neutrophils with a runx 1 mutation found that loss of neutrophils increased regeneration and loss of macrophages slowed regeneration (Li et al., 2012). Similarly, transgenic ablation to reduce macrophages also slowed fin fold regeneration (Petrie et al., 2014) and a recent study that utilised tnfr1 knockdown by morpholino suggested a role for macrophage-derived TNF signaling during fin regeneration (Nguyen-Chi etal., 2017). In agreement with these findings, glucocorticoid treatment which blocks inflammation reduces proliferation (Mathew et al., 2007, Sharif et al., 2015).

A series of papers from the Kawakami lab offer a molecular model that may help explain these apparently conflicting results (Hasegawa et al., 2017, Hasegawa et al., 2015, Yoshinari et al., 2009). Their group ablated leucocytes using the cloche and tal1 mutants as well spi $1 b$, irf8 and csf3r morpholinos. They found that between 12-24hpe, cell death is elevated and cell division is reduced and showed that this is due to a reduction in the numbers of macrophages. Surprisingly they found that these defects are accompanied by a strong and persistent elevation of il1 $\beta$ expression. As discussed above, il $1 \beta$ is expressed in the damaged epithelium and is required for activation of regeneration, so why then would it be upregulated when regeneration is reduced? To investigate further, Hasegawa et al., first showed that ectopic upregulation of il1 $\beta$ under control of a heat shock promoter is sufficient to induce cell death in the tail of unoperated larvae. They were also able to show that the deleterious effects macrophage depletion could be rescued by knock-down of il1 $\beta$ with morpholinos. In addition they found that glucocorticoid treatment inhibits expression of $i / 1 \beta$ in the epithelium and also rescues macrophage depletion. This elegant set of experiments suggests that macrophages may act upon regeneration by resolving il1 $\beta$ expression. This, along with the role of neutrophils in dampening ROS signalling, suggests that leucocytes may not initiate regeneration, but rather that they provide negative feedback to early damage-induced pathways to ensure the appropriate regenerative response. Since il $1 \beta$ is known in other systems to be activated by $\mathrm{Ca}^{2+}$ and DAMP signalling

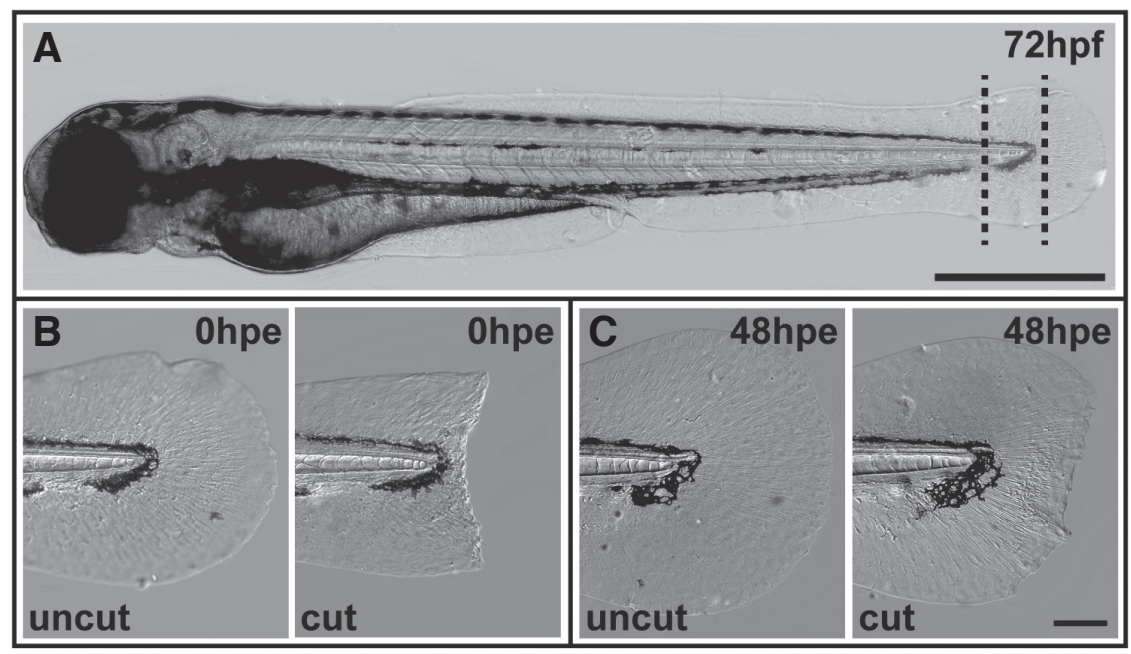


(Newton and Dixit, 2012), il1 $\beta$ is may be an inflammatory signal that serves to link damage to regeneration.

The second candidate for initiation of regeneration is ROS signalling. Rieger et al., used duox morpholinos to show that when ROS synthesis is blocked, axonal regeneration within the fin fold does is reduced (Rieger and Sagasti, 2011). The Huttenlocher lab went one step further by dissecting the role of SFKs acting downstream of ROS in the fin fold (Yoo et al., 2012). They found that the Duox inhibitor DPI and the SFK inhibitor PP2 both block leucocyte recruitment and regenerative cell proliferation. However, when they knocked down individual SFKs they found that lyn morpholinos only affect leucocytes and fynb morpholinos only affect proliferation. This uncoupling of the inflammatory and regenerative activities of ROS suggests that fynb acts as part of the trigger for regeneration. Inhibition of ROS/SFK signalling was only effective within the first hour after wounding, at a time when il1 $\beta$ is also functioning. Whether these two pathways interact or form a linear pathway has not yet been investigated.

\section{Tail regeneration}

The tail excision assay is closely related to fin fold excision except that the end of the tail is also removed (Rojas-Munoz et al., 2009). The cut is made transversely where there is a gap in the melanophores which line the ventral edge of the trunk (see Fig. 2A). The end of the neural tube and notochord as well as muscle and blood vessels are removed and recovery takes up to four days. One of the hallmarks of tail regeneration is the protrusion of notochord cells which form a clump of cells that sit under the wound epithelium during regeneration. This clump of cells forms immediately after excision and is also seen during axolotl and tadpole tail regeneration. These cells are sometimes referred to as the blastema, but there is no evidence to support this assumption. Forward genetic screens have identified mutations that affect the ErbB2 and ErbB3 receptor tyrosine kinases which disrupt tail regeneration (Rojas-Munoz et al., 2009). In addition to this study, other papers have identified chromatin remodelling components, the Wnt/ $\beta$-catenin signalling modifier Fam53b and nitric oxide synthases as being expressed during larval tail regeneration (Kizil et al., 2014, Kizil et al., 2009, Lepiller et al., 2009, Pfefferli et al., 2014). It is likely that these pathways are also active during fin fold regeneration but a direct comparison has not been made.

\section{Conclusion}

Although great progress has been made in understanding how the fin fold regenerates, there are still several key questions that remain unanswered. One fundamental issue is that of the source of the cells that reform the fin. Do stem cells or precursor cells form the blastema? Is there dedifferentiation of mature cell types or is dedifferentiation even necessary? The majority of the tissue lost is epidermal, and these cells are proliferative and move to cover the wound after excision (Mateus et al., 2012). Similarly, fin mesenchymal cells, pigment cells and leucocytes are highly migratory and may simply move to replace the lost tissue. Lineage studies of the cells that make up the blastema are needed to identify the cellular identity of new tissue. A second important question is whether regeneration of the fin fold involves the same processes as the initial development of the fin. The Wnt/ $\beta$-catenin, RA and FGF pathways all act during anterior/posterior axis elongation and it is possible that their roles during regeneration are identical to their roles during development. Alternatively, these pathways could be playing roles that are unique to regeneration. A third crucial area for analysis is how is regeneration initiated. So far the II1 $\beta$ and ROS/Fynb pathways are the best candidates to link wounding to regeneration. But a molecular mechanism for how these pathways have evolved to play this role has not emerged. Topical questions are what are the direct, molecular targets of these pathways during regeneration, and are these targets also affected by non-regenerative signalling. The tools to address these issues are readily available and it is likely that in the next few years the answers to most if not all of these questions will be revealed.

\section{Acknowledgements}

I wish to acknowledge Dr Stephen Renshaw for his critical reading of the manuscript and the Medical Research Council UK for their generous support (MR/J001457/1 to HHR).

\section{References}

CORDEIRO, J.V. and JACINTO, A. (2013). The role of transcription-independent damage signals in the initiation of epithelial wound healing. Nat Rev Mol Cell Biol 14: 249-262

DE OLIVEIRA, S., BOUDINOT, P., CALADO, A. and MULERO, V. (2015). Duox1derived $\mathrm{H} 2 \mathrm{O} 2$ modulates $\mathrm{Cxcl} 8$ expression and neutrophil recruitment via JNK/CJUN/AP-1 signaling and chromatin modifications. J Immunol 194: 1523-1533.

DE OLIVEIRA, S., LOPEZ-MUNOZ, A., CANDEL, S., PELEGRIN, P., CALADO, A and MULERO, V. (2014). ATP modulates acute inflammation in vivo through dual oxidase 1-derived $\mathrm{H} 2 \mathrm{O} 2$ production and NF-kappaB activation. J Immunol 192: 5710-5719.

EMING, S.A., WYNN, T.A. and MARTIN, P. (2017). Inflammation and metabolism in tissue repair and regeneration. Science 356: 1026-1030.

ENYEDI, B., JELCIC, M. and NIETHAMMER, P. (2016). The Cell Nucleus Serves as a Mechanotransducer of Tissue Damage-Induced Inflammation. Cell165:1160-1170.

hASEGAWA, T., HALL, C.J., CROSIER, P.S., ABE, G., KAWAKAMI, K., KUDO, A. and KAWAKAMI, A. (2017). Transient inflammatory response mediated by interleukin-1beta is required for proper regeneration in zebrafish fin fold. Elife 6.

HASEGAWA, T., NAKAJIMA, T., ISHIDA, T., KUDO, A. and KAWAKAMI, A. (2015) A diffusible signal derived from hematopoietic cells supports the survival and proliferation of regenerative cells during zebrafish fin fold regeneration. Dev Biol 399: 80-90.

HE, J., LU, H., ZOU, Q. and LUO, L. (2014). Regeneration of liver after extreme hepatocyte loss occurs mainly via biliary transdifferentiation in zebrafish. Gastroenterology 146: 789-800 e8.

HUANG, M., CHANG, A., CHOI, M., ZHOU, D., ANANIA, F.A. and SHIN, C.H. (2014). Antagonistic interaction between Wnt and Notch activity modulates the regenerative capacity of a zebrafish fibrotic liver model. Hepatology 60: 1753-1766.

ISHIDA, T., NAKAJIMA, T., KUDO, A. and KAWAKAMI, A. (2010). Phosphorylation of Junb family proteins by the Jun $\mathrm{N}$-terminal kinase supports tissue regeneration in zebrafish. Dev Biol 340: 468-479.

KAWAKAMI, A., FUKAZAWA, T. and TAKEDA, H. (2004). Early fin primordia of zebrafish larvae regenerate by a similar growth control mechanism with adult regeneration. Dev Dyn 231: 693-699.

KIZIL, C., KUCHLER, B., YAN, J.J., OZHAN, G., MORO, E., ARGENTON, F., BRAND, M., WEIDINGER, G. and ANTOS, C.L. (2014). Simplet/Fam53b is required for Wnt signal transduction by regulating beta-catenin nuclear localization. Development 141: 3529-3539

KIZIL, C., OTTO, G.W., GEISLER, R., NUSSLEIN-VOLHARD, C. and ANTOS, C.L. (2009). Simplet controls cell proliferation and gene transcription during zebrafish caudal fin regeneration. Dev Biol 325: 329-340.

KNAPPE, S., ZAMMIT, P.S. and KNIGHT, R.D. (2015). A population of Pax7-expressing muscle progenitor cells show differential responses to muscle injury dependent on developmental stage and injury extent. Front Aging Neurosci 7: 161. 
LEPILLER, S., FRANCHE, N., SOLARY, E., CHLUBA, J. and LAURENS, V. (2009). Comparative analysis of zebrafish nos2a and nos2b genes. Gene 445: 58-65.

LI, L., YAN, B., SHI, Y.Q., ZHANG, W.Q. and WEN, Z.L. (2012). Live imaging reveals differing roles of macrophages and neutrophils during zebrafish tail fin regeneration. J Biol Chem 287: 25353-25360.

LISSE, T.S., BROCHU, E.A. and RIEGER, S. (2015). Capturing tissue repair in zebrafish larvae with time-lapse brightfield stereomicroscopy. J Vis Exp. (95) e52654.

LIU, C., WU, C., YANG, Q., GAO, J., LI, L., YANG, D. and LUO, L. (2016). Macrophages Mediate the Repair of Brain Vascular Rupture through Direct Physical Adhesion and Mechanical Traction. Immunity 44: 1162-1176.

LUSH, M.E. and PIOTROWSKI, T. (2014). Sensory hair cell regeneration in the zebrafish lateral line. Dev Dyn 243: 1187-1202.

MATEUS, R., PEREIRA, T., SOUSA, S., DE LIMA, J.E., PASCOAL, S., SAUDE, L. and JACINTO, A. (2012). In vivo cell and tissue dynamics underlying zebrafish fin fold regeneration. PLoS One 7: e51766.

MATHEW, L.K., SENGUPTA, S., FRANZOSA, J.A., PERRY, J., LA DU, J., ANDREASEN, E.A. and TANGUAY, R.L. (2009). Comparative expression profiling reveals an essential role for raldh2 in epimorphic regeneration. J Biol Chem 284: 33642-33653.

MATHEW, L.K., SENGUPTA, S., KAWAKAMI, A., ANDREASEN, E.A., LOHR, C.V., LOYNES, C.A., RENSHAW, S.A., PETERSON, R.T. and TANGUAY, R.L. (2007) Unraveling tissue regeneration pathways using chemical genetics. J Biol Chem 282: 35202-35210.

MEYERS, J.R., HU, L., MOSES, A., KABOLI, K., PAPANDREA, A. and RAYMOND, P.A. (2012). beta-catenin/Wnt signaling controls progenitor fate in the developing and regenerating zebrafish retina. Neural Dev 7: 30 .

NEWTON, K. and DIXIT, V.M. (2012). Signaling in innate immunity and inflammation. Cold Spring Harb Perspect Biol 4(3). pii: a006049. doi: 10.1101/cshperspect. a006049.

NGUYEN-CHI, M., LAPLACE-BUILHE, B., TRAVNICKOVA, J., LUZ-CRAWFORD, P., TEJEDOR, G., LUTFALLA, G., KISSA, K., JORGENSEN, C. and DJOUAD, F. (2017). TNF signaling and macrophages govern fin regeneration in zebrafish larvae. Cell Death Dis 8: e2979.

NIETHAMMER, P. (2016). The early wound signals. Curr Opin Genet Dev 40: 17-22.

NIETHAMMER, P., GRABHER, C., LOOK, A.T. and MITCHISON, T.J. (2009). A tissue-scale gradient of hydrogen peroxide mediates rapid wound detection in zebrafish. Nature 459: 996-999.

O'BRIEN, G.S., MARTIN, S.M., SOLLNER, C., WRIGHT, G.J., BECKER, C.G., PORTERA-CAILLIAU, C. and SAGASTI, A. (2009a). Developmentally regulated impediments to skin reinnervation by injured peripheral sensory axon terminals. Curr Biol 19: 2086-2090.

O'BRIEN, G.S., RIEGER, S., MARTIN, S.M., CAVANAUGH, A.M., PORTERACAILLIAU, C. and SAGASTI, A. (2009b). Two-photon axotomy and time-lapse confocal imaging in live zebrafish embryos. J Vis Exp. 24: e1129.

OHNMACHT, J., YANG, Y., MAURER, G.W., BARREIRO-IGLESIAS, A., TSAROUCHAS, T.M., WEHNER, D., SIEGER, D., BECKER, C.G. and BECKER, T. (2016). Spinal motor neurons are regenerated after mechanical lesion and genetic ablation in larval zebrafish. Development 143: 1464-1474.

PARICHY, D.M., ELIZONDO, M.R., MILLS, M.G., GORDON, T.N. and ENGESZER R.E. (2009). Normal table of postembryonic zebrafish development: staging by externally visible anatomy of the living fish. Dev Dyn 238: 2975-3015.

PASE, L., LAYTON, J.E., WITTMANN, C., ELLETT, F., NOWELL, C.J., REYESALDASORO, C.C., VARMA, S., ROGERS, K.L., HALL, C.J., KEIGHTLEY, M.C. et al., (2012). Neutrophil-delivered myeloperoxidase dampens the hydrogen peroxide burst after tissue wounding in zebrafish. Curr Biol 22: 1818-1824.

PETRIE, T.A., STRAND, N.S., YANG, C.T., RABINOWITZ, J.S. and MOON, R.T. (2014). Macrophages modulate adult zebrafish tail fin regeneration. Develop ment 141: 2581-2591

PFEFFERLI, C., MULLER, F., JAZWINSKA, A. and WICKY, C. (2014). Specific NuRD components are required for fin regeneration in zebrafish. BMC Biol 12: 30

PIPALIA, T.G., KOTH, J., ROY, S.D., HAMMOND, C.L., KAWAKAMI, K. and HUGHES, S.M. (2016). Cellular dynamics of regeneration reveals role of two distinct Pax7 stem cell populations in larval zebrafish muscle repair. Dis ModelMech 9:671-684.

RIEGER, S. and SAGASTI, A. (2011). Hydrogen peroxide promotes injury-induced peripheral sensory axon regeneration in the zebrafish skin. PLoSBio/9: e1000621.

RODRIGUES, A.M., CHRISTEN, B., MARTI, M. and IZPISUA BELMONTE, J.C (2012). Skeletal muscle regeneration in Xenopus tadpoles and zebrafish larvae. BMC Dev Biol 12: 9

ROJAS-MUNOZ, A., RAJADHYKSHA, S., GILMOUR, D., VAN BEBBER, F., ANTOS, C., RODRIGUEZ ESTEBAN, C., NUSSLEIN-VOLHARD, C. and IZPISUA BELMONTE, J.C. (2009). ErbB2 and ErbB3 regulate amputation-induced proliferation and migration during vertebrate regeneration. Dev Biol 327: 177-190.

ROSENBERG, A.F., ISAACMAN-BECK, J., FRANZINI-ARMSTRONG, C. and GRANATO, M. (2014). Schwann cells and deleted in colorectal carcinoma direct regenerating motor axons towards their original path. JNeurosci34: 14668-14681.

SEGER, C., HARGRAVE, M., WANG, X., CHAI, R.J., ELWORTHY, S. and INGHAM, P.W. (2011). Analysis of Pax7 expressing myogenic cells in zebrafish muscle development, injury, and models of disease. Dev Dyn 240: 2440-2451.

SHARIF, F., STEENBERGEN, P.J., METZ, J.R. and CHAMPAGNE, D.L. (2015). Long-lasting effects of dexamethasone on immune cells and wound healing in the zebrafish. Wound Repair Regen 23: 855-865.

SIEGER, D., MORITZ, C., ZIEGENHALS, T., PRYKHOZHIJ, S. and PERI, F. (2012). Long-range $\mathrm{Ca} 2+$ waves transmit brain-damage signals to microglia. Dev Cell 22: $1138-1148$

YOO, S.K., FREISINGER, C.M., LEBERT, D.C. and HUTTENLOCHER, A. (2012) Early redox, Src family kinase, and calcium signaling integrate wound responses and tissue regeneration in zebrafish. J Cell Biol 199: 225-234.

YOO, S.K., STARNES, T.W., DENG, Q. and HUTTENLOCHER, A. (2011). Lyn is a redox sensor that mediates leukocyte wound attraction in vivo. Nature 480: 109-112.

YOSHINARI, N., ISHIDA, T., KUDO, A. and KAWAKAMI, A. (2009). Gene expression and functional analysis of zebrafish larval fin fold regeneration. Dev Bio/325:71-81

YOSHINARI, N. and KAWAKAMI, A. (2011). Mature and juvenile tissue models of regeneration in small fish species. Biol Bull 221: 62-78. 


\section{Further Related Reading, published previously in the Int. J. Dev. Biol.}

Zebrafish development and regeneration: new tools for biomedical research

Sebastiaan A. Brittijn, Suzanne J. Duivesteijn, Mounia Belmamoune, Laura F.M.Bertens, Wilbert Bitter, Joost D. de Bruijn, Danielle L. Champagne, Edwin Cuppen, Gert Flik, Christina M. Vandenbroucke-Grauls, Richard A.J. Janssen, Ilse M.L. de Jong, Edo Ronald de Kloet, Alexander Kros, Annemarie H. Meijer, Juriaan R. Metz, Astrid M. van der Sar, Marcel J.M. Schaaf, Stefan Schulte-Merker, Herman P. Spaink, Paul P. Tak, Fons J. Verbeek, Margriet J. Vervoordeldonk, Freek J. Vonk, Frans Witte, Huipin Yuan and Michael K. Richardson Int. J. Dev. Biol. (2009) 53: 835-850

https://doi.org/10.1387/ijdb.082615sb

Zebrafish keratin 8 is expressed at high levels in the epidermis of regenerating caudal fin. M L Martorana, M Tawk, T Lapointe, N Barre, M Imboden, C Joulie, J Géraudie and S Vriz Int. J. Dev. Biol. (2001) 45: 449-452

http://www.intjdevbiol.com/web/paper/11330866

Expression of two even-skipped genes eve1 and evx2 during zebrafish fin morphogenesis and their regulation by retinoic acid A Brulfert, M J Monnot and J Géraudie Int. J. Dev. Biol. (1998) 42: 1117-1124

http://www.intjdevbiol.com/web/paper/9879709

Correlation between RA-induced apoptosis and patterning defects in regenerating fins and limbs

J Géraudie and P Ferretti

Int. J. Dev. Biol. (1997) 41: 529-532

http://www.intjdevbiol.com/web/paper/9240571

Cell proliferation in fin fish regeneration

L Santos Ruiz, J A Santamaría and J Becerra

Int. J. Dev. Biol. (1996) 40: S183-S184

http://www.intjdevbiol.com/web/paper/9087753

Cell to cell interactions during teleosts fin regeneration

M Mari-Beffa, I Mateos, P Palmqvist and J Becerra

Int. J. Dev. Biol. (1996) 40: S179-S180

http://www.intjdevbiol.com/web/paper/9087751

Caudal fin regeneration in wild type and long-fin mutant zebrafish is affected by retinoic acid

J Géraudie, M J Monnot, A Brulfert and P Ferretti

Int. J. Dev. Biol. (1995) 39: 373-381

http://www.intjdevbiol.com/web/paper/7669548

5 yr ISI Impact Factor $(2016)=2.421$
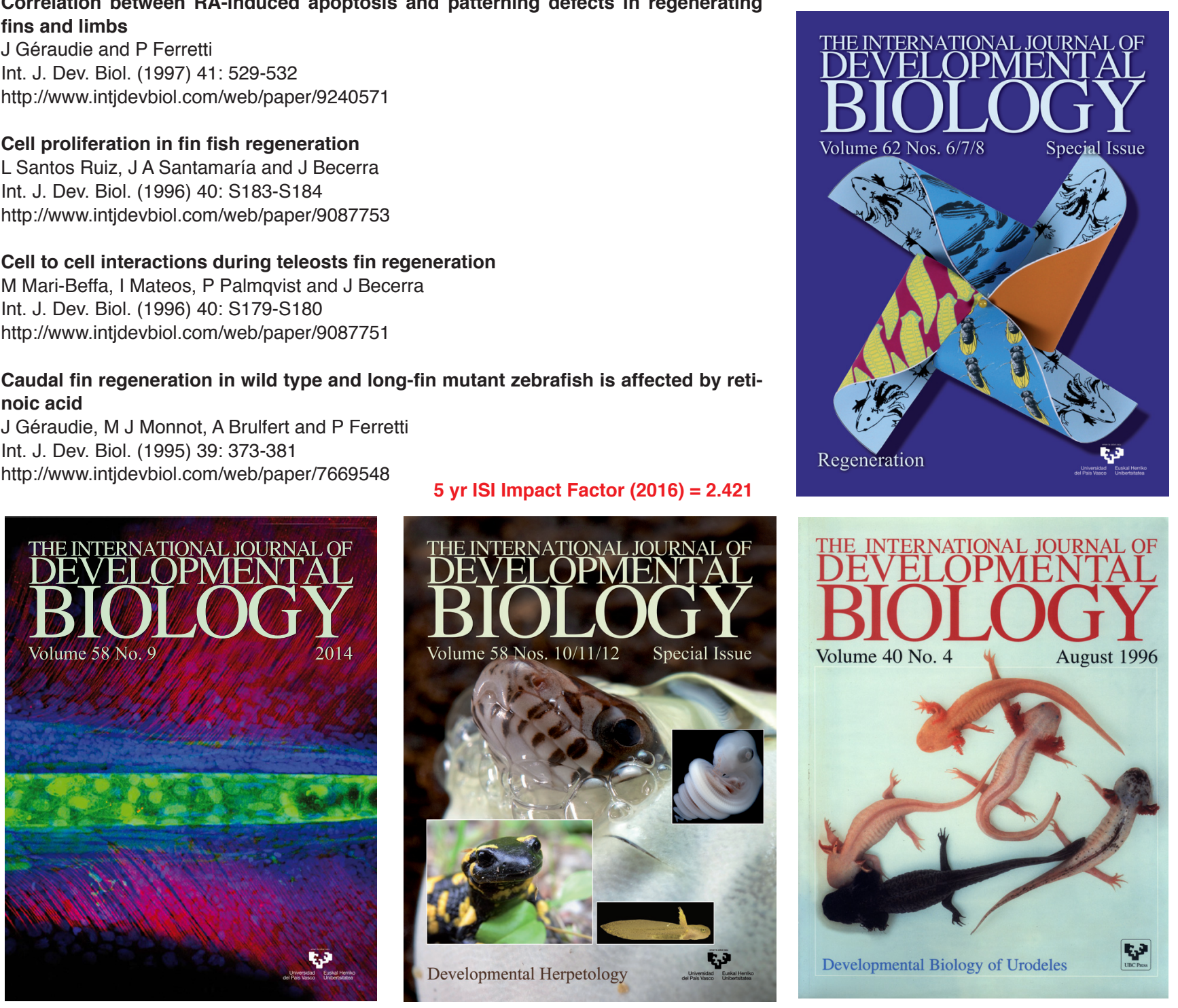